\title{
Stream hydraulics and temperature determine the metabolism of geothermal Icelandic streams
}

\author{
B.O.L. Demars( ${ }^{(1)}$, J.R. Manson ${ }^{(2)}$, J.S. Ólafsson ${ }^{(3)}$, G.M. Gíslason ${ }^{(4)}$, \\ N. Friberg ${ }^{(1,5)}$
}

Received January 26, 2011

Revised April 27, 2011

Accepted May 12, 2011

Key-words:
river,
ecosystem
functioning,
hydro-
geomorphology,
ecosystem
services

\section{ABSTRACT}

Stream ecosystem metabolism plays a critical role in planetary biogeochemical cycling. Stream benthic habitat complexity and the available surface area for microbes relative to the free-flowing water volume are thought to be important determinants of ecosystem metabolism. Unfortunately, the engineered deepening and straightening of streams for drainage purposes could compromise stream natural services. Stream channel complexity may be quantitatively expressed with hydraulic parameters such as water transient storage, storage residence time, and water spiralling length. The temperature dependence of whole stream ecosystem respiration $(E R)$, gross primary productivity (GPP) and net ecosystem production (NEP $=G P P-E R$ ) has recently been evaluated with a "natural experiment" in Icelandic geothermal streams along a $5-25{ }^{\circ} \mathrm{C}$ temperature gradient. There remained, however, a substantial amount of unexplained variability in the statistical models, which may be explained by hydraulic parameters found to be unrelated to temperature. We also specifically tested the additional and predicted synergistic effects of water transient storage and temperature on $E R$, using novel, more accurate, methods. Both ER and GPP were highly related to water transient storage (or water spiralling length) but not to the storage residence time. While there was an additional effect of water transient storage and temperature on $E R\left(r^{2}=0.57 ; P=0.015\right)$, GPP was more related to water transient storage than temperature. The predicted synergistic effect could not be confirmed, most likely due to data limitation. Our interpretation, based on causal statistical modelling, is that the metabolic balance of streams (NEP) was primarily determined by the temperature dependence of respiration. Further field and experimental work is required to test the predicted synergistic effect on ER. Meanwhile, since higher metabolic activities allow for higher pollutant degradation or uptake, river restoration and management should promote habitat diversity and complexity (hyporheic zone, macrophyte patches, substrate heterogeneity), especially for microbial activity.

(1) The James Hutton Institute, Craigiebuckler, Aberdeen AB15 8QH, UK, benoit.demars@hutton.ac.uk

(2) The Richard Stockton College, Computational Science, PO Box 195, Pomona, 08240 NJ, USA

(3) Institute of Freshwater Fisheries, Keldnaholt, 112 Reykjavik, Iceland

(4) University of Iceland, Institute of Biology, Sturlugata 7, 101 Reykjavik, Iceland

(5) National Environmental Research Institute, University of Aarhus, Department of Freshwater Ecology,

Vejlsøvej 25, PO Box 314, 8600 Silkeborg, Denmark 


\section{RÉSUMÉ}

\section{L'hydraulique fluviale et la température déterminent le métabolisme de ruisseaux géothermiques islandais}

Mots-clés : rivière, fonctionnement des écosystèmes, hydrogéomorphologie, service des écosystèmes
Le métabolisme des écosystèmes aquatiques fluviaux joue un rôle critique dans les cycles biogéochimiques planétaires. La complexité des habitats benthiques et l'aire disponible pour les microbes par rapport au volume d'eau qui s'écoule sont considérées comme des facteurs importants pour le métabolisme de l'écosystème. Malheureusement, le creusement et l'alignement des cours d'eau pour le drainage des terres pourraient compromettre les services naturels fournis par les cours d'eau. Cette complexité peut être exprimée quantitativement avec des paramètres hydrauliques tels que le stokage transitoire de l'eau dans le lit de la rivière, la durée de résidence du stockage transitoire, et la longueur du flux en hélice (ou spirale) de l'eau (distance moyenne parcourue par une molécule d'eau dans la zone d'eau courante libre avant d'entrer dans la zone calme). L'effet de la température sur la respiration globale des ruisseaux $(E R)$, productivité primaire brute (GPP) et production nette de l'écosystème (NEP) a récemment été évalué au travers d'une "expérience naturelle " dans des ruisseaux géothermiques islandais le long d'un gradient de température de $5-25^{\circ} \mathrm{C}$. II resta, cependant, une quantité substantielle de variabilité non expliquée par les modèles statistiques, qui pourrait être expliquée par les paramètres hydrauliques non reliés à la température. Nous avons aussi tout particulièrement testé les effets additionnels et en synergie du stokage transitoire de l'eau et de la température sur la respiration, en utilisant de nouvelles méthodes. ER and GPP furent hautement corrélées au stockage transitoire de l'eau (ou flux en hélice de l'eau), mais pas à la durée de résidence du stockage. Le stokage transitoire de l'eau et de la température eurent un effect additionnel sur $E R\left(r^{2}=0,57 ; P=0,015\right)$, en revanche GPP était plus liée au stockage transitoire de l'eau qu'à la température. L'effet en synergie ne put être confirmé, probablement dû aux limitations des données. Notre interpretation, basée sur un modèle statistique causal, est que l'équilibre métabolique des cours d'eau (NEP) était principalement contrainte par la réponse de la respiration à la température. D'autres travaux de terrain et expérimentaux sont nécessaires pour tester notre nouvelle hypothèse d'un effet en synergie sur ER. Dans l'attente, puisqu'une plus haute activité métabolique permet une rétention ou dégradation plus importante des polluants, la restoration et la gestion des cours d'eau devraient promouvoir la diversité et la complexité des habitats (hyporhéos, touffes de macrophytes, hétérogénéité du substrat) particulièrement pour l'activité microbienne.

\section{INTRODUCTION}

Stream ecosystem functioning plays a critical role in planetary biogeochemical cycling (including green house gas emission) and pollutant degradation from mountain to sea (e.g. Alexander et al., 2008, 2009; Battin et al., 2008, 2009). The engineered deepening and straightening of streams for drainage purposes and deforestation could compromise stream natural services (e.g. Sweeney et al., 2004). Rich nations have managed to secure water resources for human consumption but this has been at the expense of habitat diversity (Vörösmarty et al., 2010). While many studies have focused on the role of habitat diversity on biological communities, fewer have tried to quantify the effect of habitat complexity or heterogeneity on ecosystem processes (e.g. Cardinale et al., 2002; Cardinale, 2011).

Headwater streams are thought to have high metabolic rates due to continuous nutrient renewal, large stable surface area per water volume, large water transient storage (amount of temporary storage of water within quiescent zones), long storage residence time (average water residence time in the transient storage zones) and short water spiralling length (average distance travelled by a water molecule in free-flowing water before entering the water 
transient storage zone) - Battin et al. (2008). The transient storage zone is characterised by the stream bed interstices and other near stagnant water regions that occur in natural channels and the rate at which material is transferred in and out of these regions. The total volume of stream bed interstices and near stagnant water regions is often referred to as the water transient storage (and quantified as $A_{s}$, the volume of storage zone per unit length run of stream). It is generally normalised to stream cross section area $(A)$, i.e. the proportion $A_{s}: A$ (transient storage zone relative to the size of the free-flowing water), in order to make comparisons between natural streams more independent of discharge (or stream size).

Water transient storage is also often associated with the presence of a hyporheic zone (Jones and Mulholland, 2000). However, surface abiotic and biotic structure such as large pools, aquatic patches of macrophytes and biofilm development may equally generate hydrological retention (e.g. Bencala and Walters, 1983; Mulholland et al., 1994; Sand-Jensen and Mebus, 1996). Experimental studies have been especially successful in demonstrating changes in nutrient uptake with the development or manipulation of biotic structures such as biofilm and patches of aquatic macrophytes (Mulholland et al., 1994; Battin et al., 2003; Ensign and Doyle, 2005; Bottacin-Busolin et al., 2009).

Water transient storage is thought to be a good surrogate for habitat complexity or surface area availability for microbial life (e.g. Mulholland et al., 2001; the three dimension stream architecture, Battin et al., 2008). While the expected positive direct link between transient storage and whole stream metabolism (e.g. Marzolf et al., 1994) has been tentatively supported in a couple of studies (Mulholland et al., 1997; Fellows et al., 2001), the most comprehensive regional and inter-biome studies have failed to find a direct significant relationship independent of discharge (Mulholland et al., 2001; Marti et al., 2009; Bernot et al., 2010). This may be due to the modest range or relatively small transient storage, e.g. range 0.06-0.59 in Mulholland et al. (2001) and 0.01-0.44 in Marti et al. (2009) compared to 0.06-1.67 (Mulholland et al., 1997; Fellows et al., 2001) and mostly 0.05-2.7 worldwide (Battin et al., 2008). These studies were neither specifically designed to test for the effect of transient storage on stream metabolism nor very successful at explaining ecosystem respiration possibly due to high (unquantified) error of measurements for both transient storage and respiration (Cox and Runkel, 2008; Bernot et al., 2010).

The temperature dependence of whole stream ecosystem respiration $(E R)$, gross primary productivity (GPP) and net ecosystem production $(N E P=G P P-E R)$ has recently been evaluated with a "natural experiment" in Icelandic geothermal streams along a 5-25 ${ }^{\circ} \mathrm{C}$ temperature gradient (Demars et al., 2011). There remained, however, a substantial amount of unexplained variability in the statistical models, which may be explained by hydraulic parameters found to be unrelated to temperature (Demars et al., 2011). Following on from this study, we hypothesise that water transient storage, a surrogate for physical space availability for microbial communities (the metabolic engines of the ecosystem), should largely account for the remaining variability not explained by temperature. We expect water transient storage to be positively associated with ER and GPP. The strength of the relationship should be stronger with $E R$ than GPP because unlike autotrophic organisms, heterotrophic organisms can colonise the hyporheic zone and use the continual supply of DOC and autochthonous organic matter. Since both ER and GPP are expected to respond positively to water transient storage and temperature, we predict a positive additional effect. Since temperature does not only affects biological processes but also physical properties such as water viscosity, we further hypothesise that water transient storage will also have a synergistic effect with temperature on $E R$, due to increase hydraulic conductivity in the hyporheic zone. Finally stream metabolism is expected to be positively related to water storage residence time (because there is more time for nutrients to interact with the biota) and negatively related to water spiralling length (expected to be inversely related to water transient storage and water storage residence time). In the present study, we combine our new, more accurate, methodological work on transient storage (Manson et al., 2001, 2011, this study) and stream metabolism (Demars et al., 2011) to test these hypotheses. 


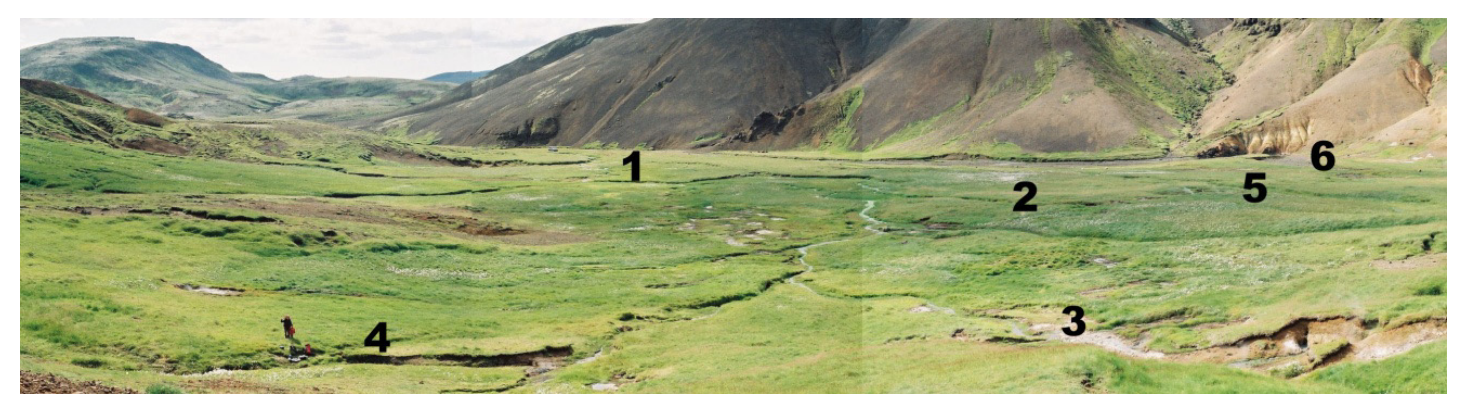

\section{Figure 1}

Panoramic view of independent stream sites 1-6 flowing from the hill where the photo was taken towards the mountains in the background in the river Hengladalsá. Site 12 is at the back of the first hill (left hand side) and all other sites $(7-11,14)$ are further up (right hand side) within $1 \mathrm{~km}$ (see map in Woodward et al., 2010).

\section{Figure 1}

Vue panoramique des stations des ruisseaux indépendants 1-6 coulant de la colline, où fut prise la photo, vers les montagnes au dernier plan, dans la rivière Hengladalsá. Le site 12 est situé derrière la colline au premier plan à gauche et tous les autres sites $(7-11,14)$ sont plus haut sur la droite à moins d'un kilomètre (voir la carte publiée dans Woodward et al., 2010).

\section{MATERIAL AND METHODS}

\section{> STUDY AREA}

The study area is situated in south-west Iceland $\left(64^{\circ} 5^{\prime} \mathrm{N}, 21^{\circ} 30^{\prime} \mathrm{W}\right)$ on the mid-Atlantic ridge between the North American and Eurasian tectonic plates and is characterised by intense volcanic and geothermal activity. Heating of the stream water is by steam from boiling geothermal water reservoirs, which heats up the upper cold groundwater that feeds the streams and the bedrock they flow through (Arnason et al., 1969). Precipitation in excess of $3000 \mathrm{~mm}$ per year infiltrates the porous volcanic bedrock and numerous small permanent streams, mostly groundwater fed, emerge from the valley side and discharge into the River Hengladalsá (see map in Woodward et al., 2010; Figure 1). We studied 13 groundwater fed streams (discharge 1-50 L. $\mathrm{s}^{-1}$ ) feeding a two kilometre reach of the Hengladalsá river, with varying degrees of natural geothermal warming $\left(5-25^{\circ} \mathrm{C}\right)$. The concentration of cations and anions of the groundwater and stream-water is similar across streams, mostly independent of temperature (Friberg et al., 2009; Demars et al., 2011). All streams were small headwaters (summer discharge 1-50 L.s ${ }^{-1}$ ) affected differently by seasonal snowmelt and rain on snow events. The nature of the stream bed varied between streams from substrata dominated by mud, gravel/cobbles in loose or stable matrix, or calcite sinter. The stream bed supported biofilm and macrophytes (filamentous algae, bryophytes or vascular plants). These physical and biological features determine stream area availability for microbes and create water transient storage zones. Further details are available in Demars et al. (2011).

\section{$>$ WHOLE STREAM METABOLISM}

We quantified the net metabolism of each stream in August 2008, when the streams were under steady state conditions, i.e. when maximum standing biomass was assumed to be reached in all streams independently of temperature. Whole stream metabolism estimates ( $E R$ and GPP) were based on a modified open-system $\mathrm{O}_{2}$ change method using two stations corrected for lateral inflows (Odum, 1956; Demars et al., 2011). Essentially, this is an in-stream mass balance of oxygen requiring measurements of oxygen inflows and outflows along a river 
reach. Stream metabolism was measured in whole stream reaches (17-51 $\mathrm{m}$ long) during $\sim 48 \mathrm{~h}$ within an 11 day period (6-16 August 2008). The instantaneous net metabolism $\left(N E P_{t}\right)$ at time $t\left(\mathrm{mg} \mathrm{O}_{2} \cdot \mathrm{m}^{-2} \cdot \mathrm{s}^{-1}\right)$ was calculated as follows (Demars et al., 2011):

$$
N E P_{t}=\left(C_{\mathrm{AV}_{t+\tau}}-C_{\mathrm{AV}_{t}}-K_{\mathrm{A}_{t}}\right) \frac{Q}{w L}-\left(C_{\mathrm{g}}-C_{\mathrm{AV}_{t}}\right) \frac{Q_{\mathrm{g}}}{w L}
$$

with $C_{\mathrm{AV}}$ averaged observed oxygen concentration $\left(\mathrm{mg} \cdot \mathrm{L}^{-1}\right)$ at time $t$ and $t+\tau$ with $\tau$ mean travel time; $K_{\mathrm{A}}$ oxygen re-aeration $\left(\mathrm{mg} \cdot \mathrm{L}^{-1}\right) ; \mathrm{Q}$, discharge $\left(\mathrm{L} \cdot \mathrm{S}^{-1}\right) ; w$, stream wetted width $(\mathrm{m})$; $L$, stream reach length $(\mathrm{m}) ; C_{\mathrm{g}}$ groundwater oxygen concentrations $\left(\mathrm{mg} \cdot \mathrm{L}^{-1}\right) ; Q_{\mathrm{g}}$ lateral inflows $\left(L \cdot S^{-1}\right)$. Typically, oxygen concentrations were measured every minute with optic oxygen sensors (TROLL9500 Professional, in-situ Inc and Universal Controller SC100, Hach Lange $\mathrm{GMBF}$ ). Conservative tracer studies ( $\mathrm{NaCl}$ and propane) were run during the same period of fieldwork to quantify discharge $(Q)$ at the top and bottom stations, groundwater lateral inflows $\left(Q_{g}\right)$, mean travel time $(\tau)$, oxygen exchange coefficient $\left(k_{\mathrm{O}_{2}}\right)$, and hydraulic parameters (see below).

Daily ecosystem respiration $(E R)$ was calculated from the net metabolism at night scaled to $24 \mathrm{~h}$ and gross primary productivity (GPP) resulted from subtracting the dark from the light metabolism and averaged over $24 \mathrm{~h}$. The daily net ecosystem production (NEP) was calculated as GPP minus $E R$, with the assumption that autotrophic and heterotrophic respiration were the same under light conditions as those measured at night. The relative uncertainties (based on 1 standard deviation) in daily ER and GPP were generally around 50\% (38-86\%) and $20 \%(1-57 \%)$, respectively. Further details about the method are available in Demars et al. (2011).

\section{> STREAM HYDRAULIC PARAMETERS}

Water transient storage and storage exchange rate with free-flowing water were determined using the upstream-downstream conductivity curves (10 s time step) produced by $\mathrm{NaCl}$ slug injections and the equations developed by Bencala and Walters (1983). The equations were solved numerically using the DISCUS method (Manson et al., 2001; see hydraulic model description below), which is an improvement on the traditional OTIS method (Cox and Runkel, 2008). The good fit of the model simulations to the experimental data, together with Damkohler numbers within the range 0.5-5 (observed range 0.9-4.3) indicated that the model output was an accurate reflection of the actual stream processes (Hart et al., 1999; Argerich et al., 2008). To obtain more comparable measurements across streams, the cross-sectional area of the storage zone was normalised by the stream cross-sectional area $\left(A_{s}: A\right)$. These stream hydraulic parameters were statistically unrelated to temperature (Demars et al., 2011), but related to each others $(r=0.64, n=13, P=0.018)$. An additional hydraulic parameter, the water spiralling length, average distance travelled by a water molecule in the free-flowing water before entering the water transient storage zone, is also reported.

\section{> HYDRAULIC MODEL DESCRIPTION}

The transport of an introduced conservative tracer in a stream with transient storage regions may be described by the following mass conservation equations,

$$
\begin{aligned}
\frac{\partial c}{\partial t}+u \frac{\partial c}{\partial x} & =D \frac{\partial^{2} c}{\partial x^{2}}+\alpha(s-c)-\frac{q}{A} c \\
\frac{\partial s}{\partial t} & =-\alpha \frac{A}{A_{s}}(s-c)
\end{aligned}
$$


where $c$ is the concentration of tracer in the main channel, $u$ is average water velocity $\left(\mathrm{m} \cdot \mathrm{s}^{-1}\right)$, $s$ is the concentration of tracer in the transient storage zone, $A$ is the stream channel crosssectional area $\left(\mathrm{m}^{2}\right), A_{\mathrm{s}}$ is the transient storage cross-sectional area $\left(\mathrm{m}^{3} \cdot \mathrm{m}^{-1}\right.$ or $\left.\mathrm{m}^{2}\right), D$ is the longitudinal dispersion coefficient, $\alpha$ is the solute exchange parameter between the main channel and the storage zones $\left(\mathrm{s}^{-1}\right), q$ is the lateral volumetric inflow rate per unit length $\left(\mathrm{m}^{3} \cdot \mathrm{s}^{-1} \cdot \mathrm{m}^{-1}\right), x$ is the longitudinal spatial co-ordinate and $t$ is time $(\mathrm{s})$.

For the experiment described herein we are concerned with solving these equations over some stream reach length, $L$, and over some time interval, $T$ during which the tracer experiment takes place. The solution to these equations are functions of space and time: $c(x, t)$ and $s(x, t)$. The following boundary conditions are appropriate for the scenario in this experiment. At the upstream boundary the tracer concentration entering the reach is specified for all time, $t=0$ to $T$; at the downstream boundary a zero diffusive flux is assumed which implies that solute is advected out of the domain unhindered. For the initial conditions all $c$ and $s$ are assumed zero at $t=0$.

The model equations are discretised using a control (or finite) volume approach, evaluating the advection term explicitly in time using a semi-Lagrangian method (Manson and Wallis, 1995) and by evaluating the dispersion and transient storage terms implicitly in time using the Crank-Nicholson method which apportions equal weight to both present and future values of $c$ and $s$ (Hoffman, 1992). The solution consists of estimates for $c$ and $s$ over some discretised spatial and temporal domain, i.e. $\left(c_{i}^{n}, s_{i}^{n}\right)$ for $i=1$ to $n_{x}$ and $m=1$ to $n_{t}$ where $n_{x}$ is the number of points in the spatial domain and $n_{t}$ is the number of points in the temporal domain. Note that the spatial domain is split into $\left(n_{x}-1\right)$ elements of size $\Delta x$ and the temporal domain is split into $\left(n_{t}-1\right)$ time steps of size $\Delta t$. Equation (1) is an advection-diffusiondecay equation and represents a considerable challenge to existing numerical methods. In order to achieve a satisfactory solution the DISCUS method (Manson and Wallis, 1995, 2000) is adopted. This method employs a conservative semi-Lagrangian algorithm that combines a control volume discretisation, the method of characteristics and a flux-based interpolation scheme. The method and its accuracy portrait is explained in detail elsewhere (Manson et al., 2001) but note that this work improves upon the numerical solution by incorporating the Crank-Nicholson method for the dispersion and transient storage terms. The discretised form of these equations is a coupled pair of equations linking $c_{i}$ and $s_{i}$ to their neighbouring cells for all the computational domain at the future time level, $n+1$,

$$
\begin{aligned}
\alpha_{i} c_{i-1}^{n+1}+\beta_{i} c_{i}^{n+1}+\gamma_{i} c_{i+1}^{n+1}+\delta_{i} s_{i}^{n+1} & =\varepsilon_{i} \\
\beta_{i}^{S} c_{i}^{n+1}+\delta_{i}^{s} s_{i}^{n+1} & =\varepsilon_{i}^{s}
\end{aligned}
$$

in which $\alpha_{i}, \beta_{i}, \gamma_{i}, \delta_{i}, \varepsilon_{i}, \beta_{i}^{s}, \delta_{i}^{s}, \varepsilon_{i}^{s}$ are coefficients related to both physical and numerical parameters. Since there are $\left(n_{x}-1\right)$ cells the resulting $2\left(n_{x}-1\right)$ equations are assembled into a matrix and solved to give $c_{i}^{n+1}$ and $s_{i}^{n+1}$ for each computational cell. Note that equation (4) may be arranged to eliminate the transient storage term from equation (3) before solving.

The model prediction for concentration versus time at the downstream end of the experimental reach is fitted to the observed data which has been collected at $n_{t}$ points in time. A fitting parameter may be defined as,

$$
E=\sum_{j=1}^{n_{t}}\left(c_{n_{x}}^{\text {observed }}-c_{n_{x}}^{\text {predicted }}\right)^{2} .
$$

The model is fitted to the observations by adjusting the parameters $\left(u, D, k_{1}=\alpha, k_{2}=\alpha A: A_{s}\right)$ strategically in order to minimize $E$. Note that lateral inflow $(q)$ is obtained independently (from discharge calculations at the top and bottom stations) and therefore not adjusted as a fitting parameter. The direct search method which was used is a SIMPLEX method of the NelderMead variety (Lagarias et al., 1998). The numerical solution was coded in FORTRAN and then compiled and linked with the MATLAB mex libraries to create a DLL which is a callable function within MATLAB. 

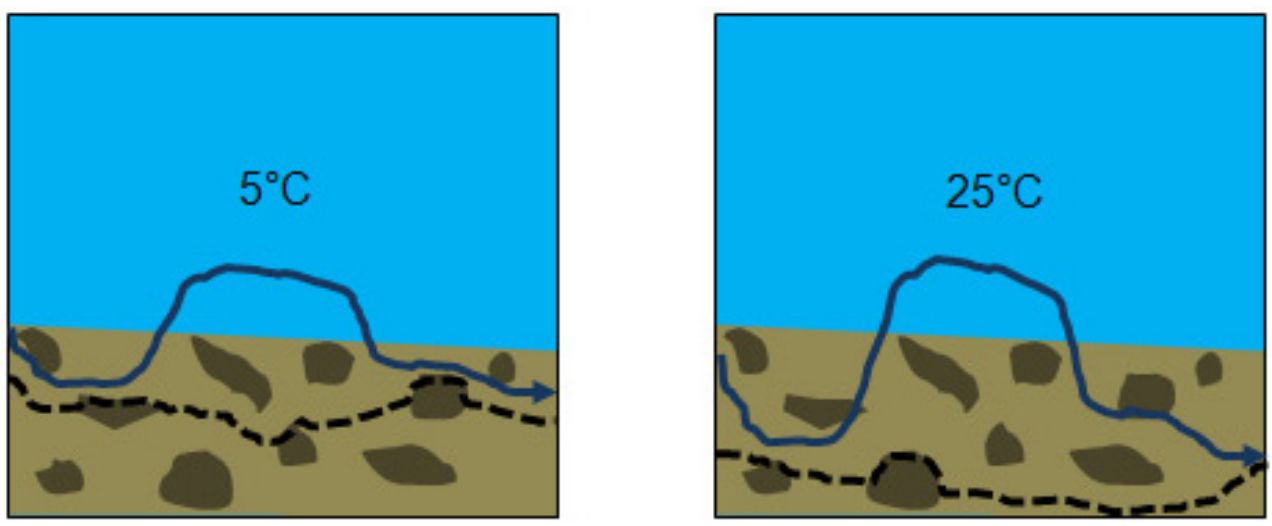

\section{Figure 2}

Two longitudinal stream sections with identical water transient storage $\left(A_{\mathrm{s}}: A\right)$ but different water temperatures. Horizontal axis is distance $(m)$ and vertical axis depth $(m)$ of the stream water (light blue) and river bed with stones (brown). The dark blue arrow represents the flow of an average water molecule through the main channel and the river bed. The horizontal distance travelled by this average water molecule in the stream water, before it flows again within the river bed (hyporheic zone), is the water spiralling length. Note the expanding volume of hyporheic zone (black dotted line) with temperature due to the lower viscosity of water resulting in a higher water hydraulic conductivity in the warm stream.

\section{Figure 2}

Deux sections longitudinales d'un ruisseau avec le même stockage transitoire de l'eau $\left(A_{s}: A\right)$ mais à des températures de l'eau différentes. L'axe horizontal est la distance $(\mathrm{m})$ et l'axe vertical représente la profondeur de la colonne d'eau (bleu) et du lit de la rivière avec les pierres (marron). La flèche en bleu foncé indique le parcours moyen d'une molécule d'eau à travers la colonne d'eau et le lit de la rivière. La distance horizontale moyenne parcourue par cette molécule d'eau dans la colonne d'eau, avant d'être reprise par le lit de la rivière (hyporhéos, délimité par la ligne noire épaisse en pointillée), est la longueur du flux en hélice (ou spirale) de l'eau. Remarquez l'expansion du volume de l'hyporhéos avec la temperature due à la moindre viscosité de l'eau qui résulte en une plus haute conductivité hydraulique dans le ruisseau chaud.

Rational for the synergistic effect of temperature $\times$ water transient storage on ER. The viscosity of water is nearly half between $5{ }^{\circ} \mathrm{C}$ and $25^{\circ} \mathrm{C}$ resulting in a direct decrease in hydraulic conductivity of water through the stream bed (Constantz and Murphy, 1991; Constantz, 1998; Swanson and Cardenas, 2010). Therefore at equal water transient storage $A_{\mathrm{s}}: A$, the hyporheic zone of a cold $\left(5^{\circ} \mathrm{C}\right)$ stream will have a smaller volume than a warm $\left(25^{\circ} \mathrm{C}\right)$ stream (assuming identical porosity for the hyporheic zone) - Figure 2. This means that the spatial availability for microbial activity is not simply a function of the water transient storage but also temperature. Hence temperature and water transient storage should have a synergistic effect on $E R$ due to the microbial activity in the hyporheic zone (Figure 3).

\section{> DATA ANALYSES}

Metabolic activities were In transformed prior to regression and correlation analyses to normalise the data and reduce heteroscedasticity or because the biological response to environmental variables was known to be exponential from previous work. We then used linear regression models (S-Plus 7.0 software, Insightful Corp.) and partial linear regression models (Canoco 4.5, Microcomputer Power) to report probabilities. All uncertainties reported are based on $\pm 1 \mathrm{SD}$ and were propagated throughout the calculations.

The hydraulic parameters of the present study were as follows: water transient storage, $A_{s}: A$; storage residence time, $A_{s}:(\alpha A)$; and water spiralling length, $u: \alpha$. 


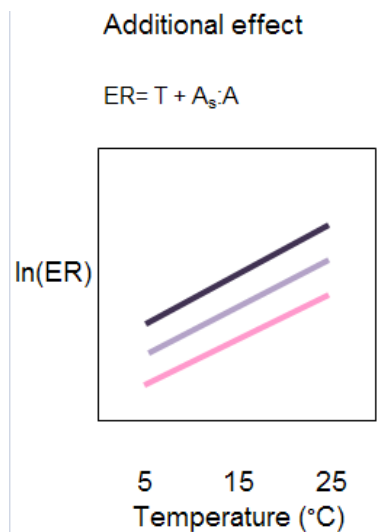

Additional and synergistic effect

$E R=T+A_{s}: A+T \times A s: A$

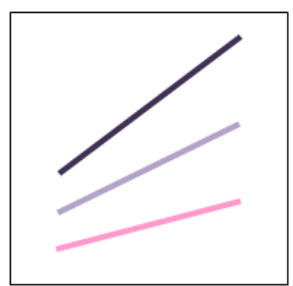

$5 \quad 15 \quad 25$

Temperature $\left({ }^{\circ} \mathrm{C}\right)$

\section{Figure 3}

Expected whole stream respiration (ER) response to increasing temperature and three sizes of water transient storage (small $A_{s}: A$, pink; intermediate $A_{s}: A$, purple; large $A_{s}: A$, dark purple).

\section{Figure 3}

Réponse prédite de la respiration $(E R)$ à l'accroissement de la température pour trois tailles de stockage transitoire de l'eau (petit $A_{s}: A$, rose; moyen, violet; large, violet foncé).

\section{Table I}

Averaged temperature, whole stream metabolism and hydraulic variables.

\section{Tableau}

Température moyenne, métabolisme de l'écosystème et variables hydrauliques.

\begin{tabular}{|c|c|c|c|c|c|c|c|}
\hline Site & $\begin{array}{l}T^{\#} \\
\left({ }^{\circ} \mathrm{C}\right)\end{array}$ & $\begin{array}{c}Q^{\prime \prime} \\
\left(L \cdot s^{-1}\right)\end{array}$ & $\begin{array}{c}E R^{*} \\
\left(\mathrm{~g} \mathrm{O}_{2} \cdot \mathrm{m}^{-2} \cdot \text { day }^{-1}\right)\end{array}$ & $\begin{array}{c}G P P^{* *} \\
\left(\mathrm{~g} \mathrm{O}_{2} \cdot \mathrm{m}^{-2} \cdot \text { day }^{-1}\right)\end{array}$ & $A_{s}: A^{t}$ & $\begin{array}{c}T_{\text {storage }}^{8} \\
\text { (s) }\end{array}$ & $\begin{array}{l}S_{\text {water }} \\
(\mathrm{m})\end{array}$ \\
\hline 1 & 18.9 & 17 & 28.2 & 20.3 & 0.55 & 131 & 38 \\
\hline 2 & 19.9 & 3 & 18.8 & 14.3 & 0.47 & 719 & 63 \\
\hline 3 & 22.6 & 7 & 17.1 & 4.9 & 0.34 & 212 & 61 \\
\hline 4 & 10.1 & 1 & 2.5 & 2.2 & 0.18 & 193 & 203 \\
\hline 5 & 20.6 & 29 & 38.0 & 27.6 & 0.51 & 119 & 72 \\
\hline 6 & 19.6 & 7 & 18.3 & 16.8 & 0.22 & 259 & 139 \\
\hline 7 & 7.2 & 4 & 7.0 & 4.4 & 0.25 & 193 & 95 \\
\hline 8 & 25.0 & 37 & 66.8 & 13.6 & 0.27 & 112 & 104 \\
\hline 9 & 18.2 & 3 & 25.5 & 15.7 & 0.73 & 923 & 75 \\
\hline 10 & 4.9 & 4 & 23.9 & 10.4 & 0.35 & 316 & 40 \\
\hline 11 & 12.8 & 5 & 9.7 & 9.2 & 0.15 & 208 & 152 \\
\hline 12 & 13.5 & 50 & 11.4 & 4.2 & 0.21 & 127 & 69 \\
\hline 14 & 9.0 & 14 & 4.1 & 2.2 & 0.12 & 131 & 184 \\
\hline
\end{tabular}

\footnotetext{
\# Temperature.
}

II Discharge.

* Ecosystem respiration.

** Gross primary productivity.

† Water transient storage (temporary storage of water within quiescent zones).

$\S$ Storage residence time (average water residence time in the transient storage zones).

* Water spiralling length (average distance travelled by a water molecule in free-flowing water before entering the water transient storage zone).

\section{RESULTS}

Water transient storage $\left(A_{s}: A\right.$, amount of temporary storage of water within quiescent zones) ranged from 0.12 to 0.73 ; storage residence time, $A_{s}:(\alpha A)$, average water residence time in the transient storage zones, ranged from 2 to $15 \mathrm{~min}$; and water spiralling length ( $u: \alpha$, average distance travelled by a water molecule before entering the water transient storage zone) ranged from 38 to $203 \mathrm{~m}$ (Table l). 


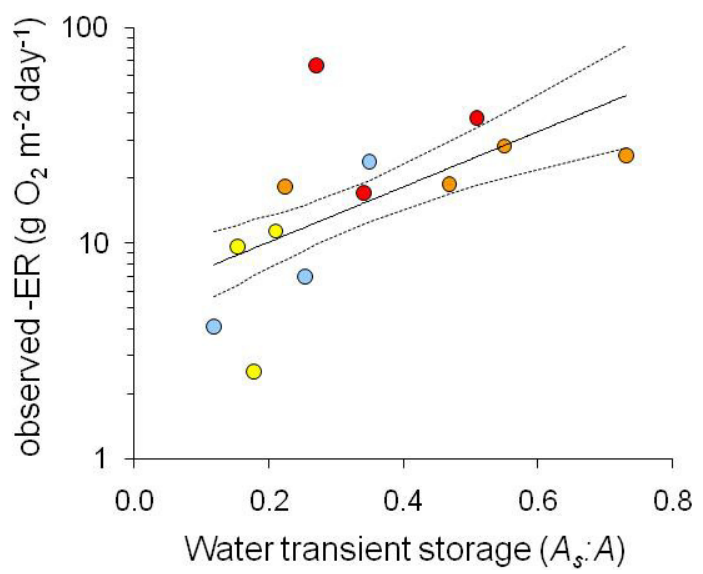

\section{Figure 4}

Ecosystem respiration, water transient storage and temperature. Top panel, ER response to water transient storage $\left(A_{s}: A\right), \ln (E R)=2.93 \pm 1.21\left(A_{s}: A\right)+1.73 \pm 0.46, r^{2}=0.35, P=0.034$. Note the negative sign on the $y$ axis indicating oxygen consumption. Bottom panel, ER response to the additional effect of temperature and water transient storage, $\ln (E R)=0.07 \pm 0.03(T)+1.86 \pm 1.13\left(A_{s}: A\right)+0.94 \pm 0.52$, $r^{2}=0.57, P=0.015$. Dashed lines represent the $68 \%$ confidence interval. Colour symbols relate to temperature (blue $<10$, yellow $10-15$, orange $15-20$, red $>20^{\circ} \mathrm{C}$ ).

\section{Figure 4}

Respiration de l'écosystème, stockage transitoire de l'eau et température. Panel du haut, réponse de la respiration $(E R)$ au stockage transitoire de l'eau $\left(A_{s}: A\right), \ln (E R)=2,93 \pm 1,21\left(A_{s}: A\right)+1,73 \pm 0,46 ; r^{2}=0,35$; $P=0,034$. Le signe négatif de l'ordonnée indique la consommation d'oxygène par la respiration. Panel du bas, réponse de $E R$ à l'effet additionnel de la température de l'eau $(T)$ et du stockage transitoire de l'eau, $\ln (E R)=0,07 \pm 0,03(T)+1,86 \pm 1,13\left(A_{s}: A\right)+0,94 \pm 0,52 ; r^{2}=0,57 ; P=0,015$. Les lignes en pointillés indiquent l'intervalle de confiance à $68 \%$. La couleur des symboles représente la température (bleu $<10$, jaune $10-15$, orange $15-20$, rouge $>20^{\circ} \mathrm{C}$ ).

Water transient storage was a significant predictor of $E R\left(r^{2}=0.35, P=0.034\right.$, Figure 4). There was a significant additive effect of temperature and $A_{s}: A$ on $E R\left(r^{2}=0.57, P=0.015\right.$, Figure 4). The more complicated model including the additional and interaction effects explained more variability in $E R\left(r^{2}=0.80, P=0.002\right)$. However the combination of the two factors $\left(A_{s}: A \times\right.$ temperature) inhibiting each other's effect (interference) was counter intuitive and of no biophysical meaning (Table II, Figure 5). Despite the significant relationship between $A_{s}: A$ and the storage residence time (average water residence time in the transient storage zones), there was no relationship between the storage residence time and $E R\left(r^{2}=0.03\right.$, $P=0.59)$. Like $E R, G P P$ was related to the water transient storage $\left(r^{2}=0.45, P=0.012\right.$, Figure 6) and not to the storage residence time $\left(r^{2}=0.08, P=0.33\right)$, and there was no significant additional or interaction effects with temperature (as expected). In fact, GPP was 


\section{Table II}

Analysis of variance table of the synergistic model with water residence time (terms added sequentially first to last), $\ln (E R)=0.31 \pm 0.08 T+16 \pm 4\left(A_{s}: A\right)-0.84 \pm 0.26\left(A_{s}: A\right) \times T-2.8 \pm 1.2, r^{2}=0.80, n=13$, $P=0.002$.

\section{Tableau II}

Analyse de variance du modèle statistique en synergie (variables ajoutées séquentiellement), $\ln (E R)=$ $0,31 \pm 0,08 T+16 \pm 4\left(A_{s}: A\right)-0,84 \pm 0,26\left(A_{s}: A\right) \times T-2,8 \pm 1,2 ; r^{2}=0,80, n=13, P=0,002$

\begin{tabular}{|l|r|r|r|c|}
\cline { 2 - 5 } \multicolumn{1}{c|}{} & Degree of freedom & Sum of square & $F$ value & $P(F)$ \\
\hline $\boldsymbol{T}^{\dagger}$ & 1 & 4.43 & 20.4 & 0.001 \\
\hline $\boldsymbol{W} \boldsymbol{T} \boldsymbol{S}^{\S}$ & 1 & 1.13 & 5.2 & 0.048 \\
\hline $\boldsymbol{T} \times \boldsymbol{W T S}$ & 1 & 2.27 & 10.5 & 0.010 \\
\hline Residuals & 9 & 1.95 & & \\
\hline
\end{tabular}

$\dagger$ Temperature.

$\S$ Water transient storage $\left(A_{\mathrm{s}}: A\right)$.

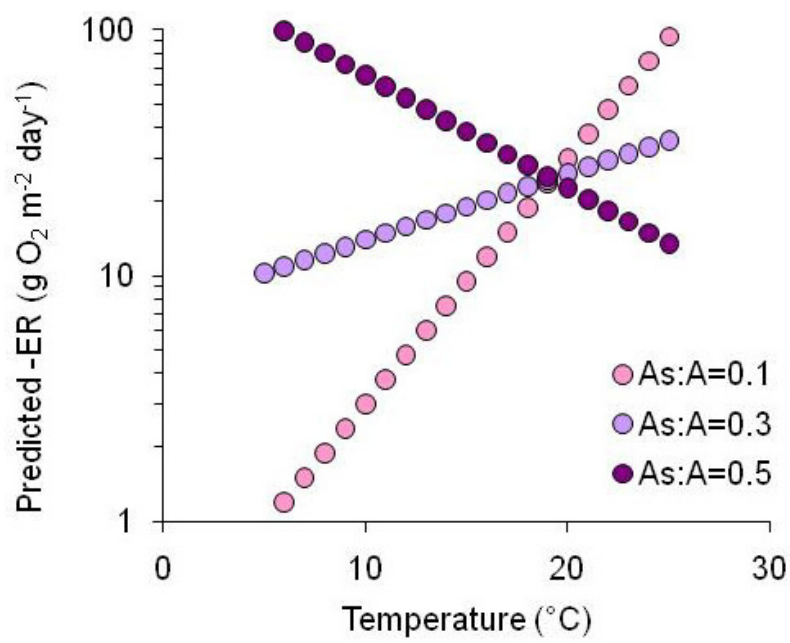

\section{Figure 5}

The synergistic model. Predicted ecosystem respiration (ER) plotted against stream water temperature for three sizes of water transient storage, based on ER response to stream water temperature $(T)$, water transient storage $\left(A_{s}: A\right)$, and their interaction, $r^{2}=0.80, n=13, P=0.002$, see Table II. This more complex model must be rejected because it has no biophysical meaning (cf. Figure 3).

\section{Figure 5}

Réponse prédite de la respiration (ER) à l'accroissement de la température pour trois tailles de stockage transitoire de l'eau, basée sur le modèle en synergie, $r^{2}=0,80, n=13, P=0,002$, voir Table II. Ce modèle plus complexe doit être rejeté pour son manque de réalité bio-physique (cf. Figure 3).

more related to water transient storage $\left(r^{2}=0.23, P\left(A_{s}: A \mid T\right)=0.047\right)$ than temperature $\left(r^{2}=0.11, P\left(T \mid A_{s}: A\right)=0.15\right)$ - with $P(a \mid b)$ indicating a conditional probability.

The water spiralling length $(S)$ was unrelated to temperature $\left(r^{2}=0.08, P=0.34\right)$ and storage residence time $\left(r^{2}=0.06, P=0.42\right)$. However there was a strong non-linear negative relationship with the relative size of the transient storage (Figure 7), a relationship for which a function could be derived from first principle. The water spiralling length was linearly and negatively related to $E R\left(r^{2}=0.49, P=0.007\right)$ and $\operatorname{GPP}\left(r^{2}=0.32, P=0.043\right)$ - see Figure 8 .

The results obtained so far indicated that water transient storage is equally important to temperature in explaining the variability in absolute metabolic rate of $E R$ and GPP, but temperature controlled more strongly the metabolic balance (NEP) of these streams via its stronger effect on respiration than photosynthesis (Figure 9). 


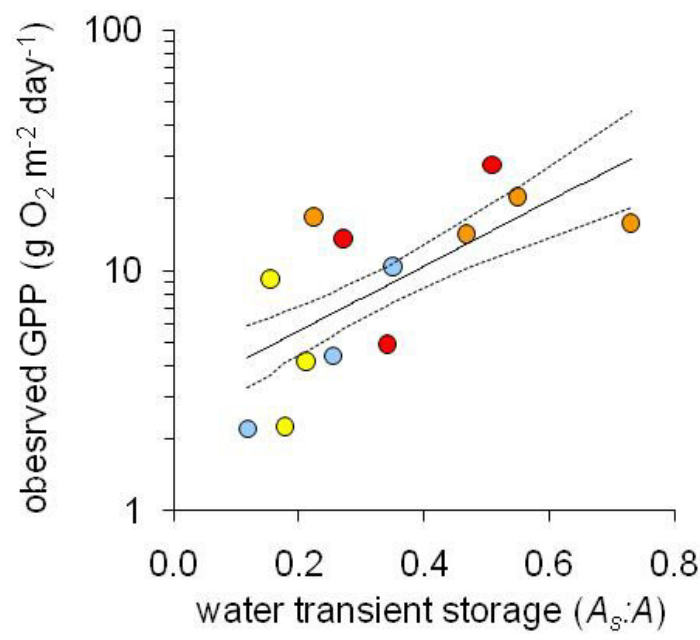

\section{Figure 6}

Gross primary productivity (GPP) response to water transient storage $\left(A_{s}: A\right), \ln (G P P)=3.08 \pm 1.02$ $\left.\left(A_{s}: A\right)+1.11 \pm 0.39, r^{2}=0.45, P=0.012\right)$. Colour symbols relate to temperature as in Figure 4.

\section{Figure 6}

Réponse de la productivité primaire brute $(G P P)$ au stockage transitoire de l'eau $\left(A_{s}: A\right), \ln (G P P)=3,08 \pm$ $\left.1,02\left(A_{s}: A\right)+1,11 \pm 0,39 ; r^{2}=0,45 ; P=0,012\right)$. La couleur des symboles est la même qu'en Figure 4.

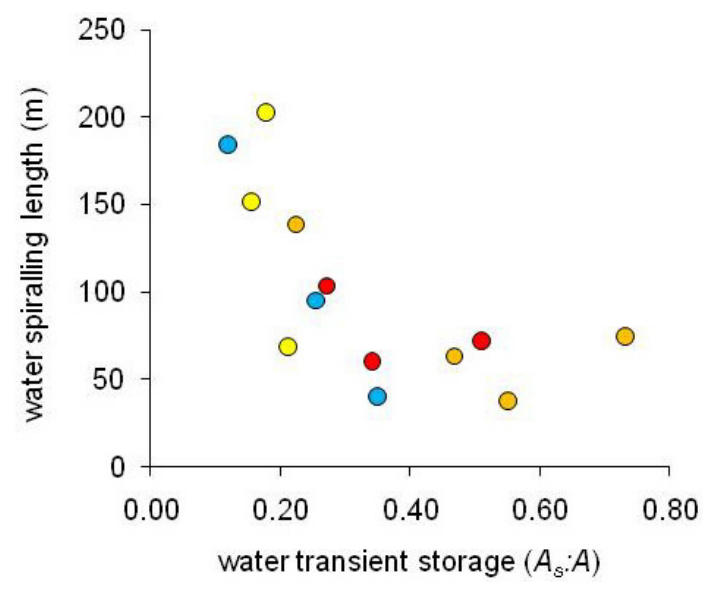

\section{Figure 7}

Non-linear relationship between water spiralling length and water transient storage. Colour symbols relate to temperature as in Figure 4.

\section{Figure 7}

Relation non linéaire entre le stockage transitoire de l'eau et la longueur du flux en hélice de l'eau. La couleur des symboles est la même qu'en Figure 4.

\section{DISCUSSION}

\section{>METABOLIC RESPONSE TO TRANSIENT STORAGE AND TEMPERATURE}

The observed range in water transient storage $\left(A_{s}: A, 0.12-0.73\right)$ was moderate compared to mostly 0.05 to 2.7 worldwide (Battin et al., 2008). Despite that, significant direct linkages were established between transient storage and stream metabolism (ER, GPP), most likely because the streams were more comparable than in previous studies (by Mulholland et al., 2001; Bernot et al., 2010) and better methods were used to estimate transient storage (Manson et al., 2001, 2011) and stream metabolism (Demars et al., 2011). 

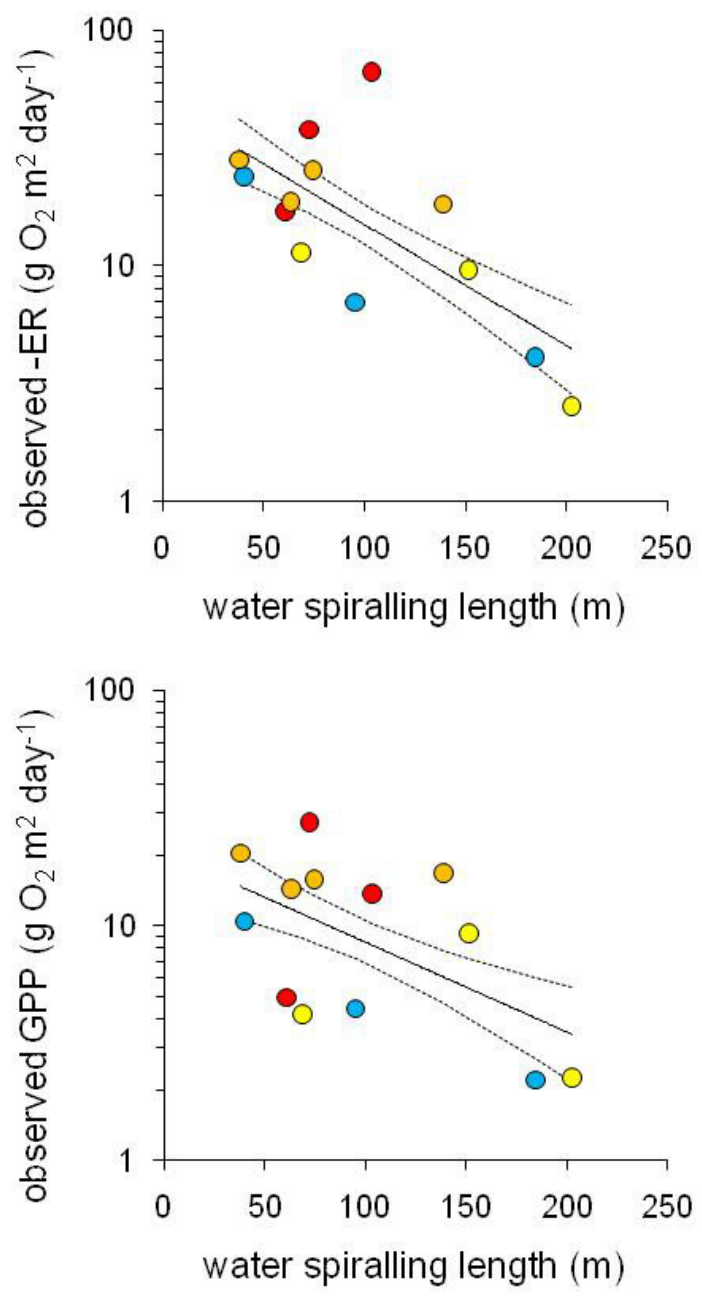

\section{Figure 8}

Whole stream respiration (ER) and gross primary productivity (GPP) response to water spiralling length. The regression models are $\ln (E R)=-0.0118 \pm 0,0036(S)+3.89 \pm 0.40, r^{2}=0.49, P=0.007$ and $\ln (G P P)=-0.0088 \pm 0.0039(S)+3.02 \pm 0.43, r^{2}=0.32, P=0.043$. Colour symbols relate to temperature as in Figure 4.

\section{Figure 8}

Réponse de la respiration (ER) et productivité primaire brute (GPP) des ruisseaux à la longueur du flux en hélice de l'eau $(S)$. Les modèles sont $\ln (E R)=-0,0118 \pm 0,0036(S)+3,89 \pm 0,40 ; r^{2}=0,49 ; P=0,007$ et $\ln (G P P)=-0,0088 \pm 0,0039(S)+3,02 \pm 0,43 ; r^{2}=0,32 ; P=0,043$. Les lignes en pointillés indiquent l'intervalle de confiance à $68 \%$. La couleur des symboles est la même qu'en Figure 4.

Surprisingly, ER did not respond much more strongly to water transient storage than GPP, as seen by the equivalent slope ( $3.1 \pm 1.0$ versus $3.0 \pm 1.2$, respectively) and statistically indistinguishable intercept $(1.7 \pm 0.5$ versus $1.1 \pm 0.4$ respectively), the latter possibly due to a lack of statistical power. Hence, there is no clear support for the hypothesis that $E R$ should exceed GPP at a given temperature due to the potentially larger spatial availability for heterotrophic microbes able to colonise the hyporheic zone compared to autotrophic microbes confined to the lit bed area. It may be that the hyporheic zone of the stream investigated has a similar area for microbes to the three dimension architecture of macrophytes present in many streams. Alternatively, it is also possible that GPP is only indirectly influenced by water transient storage, via increased respiration activity (mineralization) re-circulating the limiting nutrients essential for photosynthesis activity (recall the tight inferred feedback loop between GPP and ER, see Figure 9). 


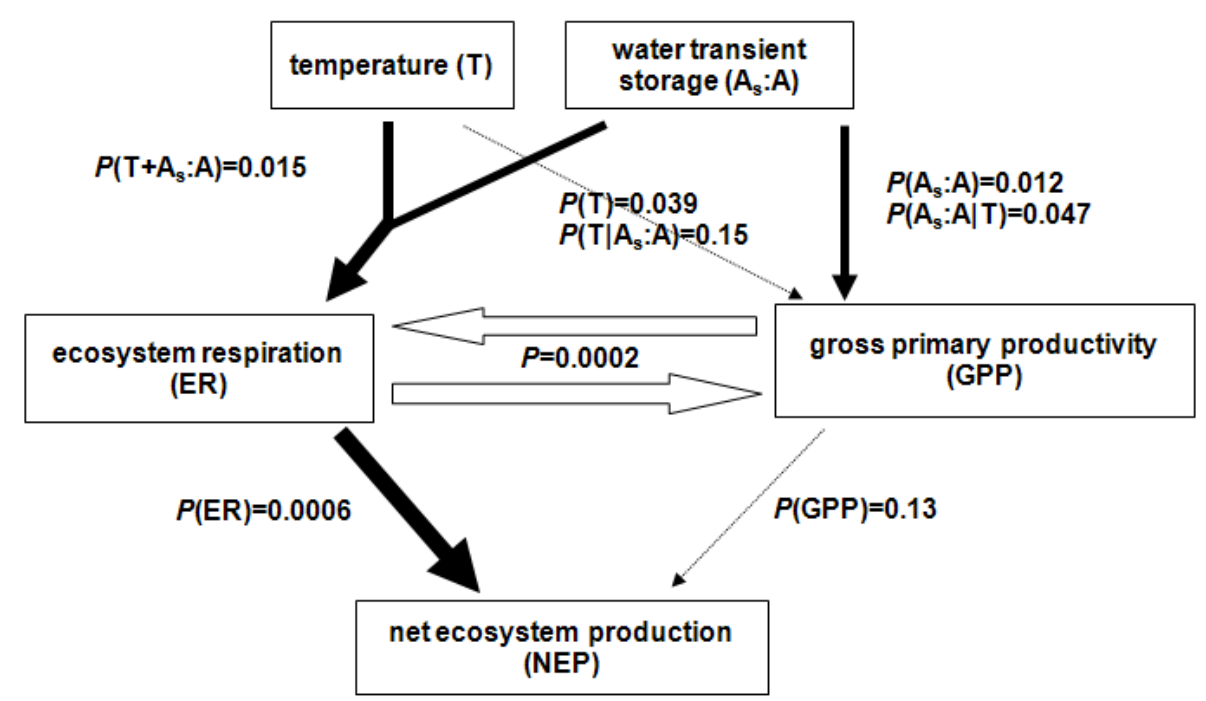

\section{Figure 9}

Causal modelling based on simple, multiple and partial regressions. The thickness of the causal arrows (filled) represents the strength $\left(r^{2}\right)$ of the significant regressions. Dashed arrows represent hypothetical pathways which were not significant, some only after consideration of other causal pathways. Probabilities associated with arrows are also reported. While the direct role of temperature on the metabolic balance (NEP) was relatively weak $\left(r^{2}=0.23, P=0.099\right.$, Demars et al., 2011), its indirect role via respiration, itself influenced as well by water transient storage and GPP, was strong. There is a positive feedback loop (open arrows) between ER and GPP in those nutrient (N, P) poor streams: GPP provides additional organic matter and $E R$ allows recycling of the limiting nutrients $(N, P)$ by mineralization of dead autotrophic matter. Note that the water transient storage may also partly result from biotic activities (patches of macrophytes, matrix of extracellular polymeric substances produced by algae and bacteria).

\footnotetext{
Figure 9

Modèle causal basé sur des régressions linéaires simples, multiples et partielles. L'épaisseur des flèches causales (noires) représente la robustesse $\left(r^{2}\right)$ des régressions. Les flèches en pointillés marquent les hypothèses causales attendues mais non-vérifiées, certaines après considération d'autres causes alternatives. Les probabilités associées sont aussi rapportées. Tandis que le rôle direct de la température sur la balance métabolique (production nette de l'écosystème NEP = productivité primaire brute GPP respiration $E R)$ était relativement faible $\left(r^{2}=0,23 ; P=0,099\right.$; Demars et al., 2011), son rôle indirect par la respiration, elle-même aussi influencée par le stockage transitoire de l'eau et la productivité primaire, est fort. II y a une boucle de rétro-contrôle positif (flèches blanches) entre la respiration (ER) et la photosynthèse (GPP) dans ces ruisseaux pauvres en nutriments $(N, P)$ : GPP fournit de la matière organique et $E R$ permet le recyclage des éléments nutritifs limitants $(N, P)$ par la minéralisation de la matière autotrophique morte. Notez que le stockage transitoire de l'eau pourrait aussi être en partie le résultat d'activités biotiques (touffes de macrophytes, matrice de substances polymériques extra-cellulaires produites par les algues et les bactéries).
}

Log transformed $E R$ and GPP were more linearly related to the water spiralling length $(S=u: \alpha)$ than water transient storage $\left(A_{s}: A\right)$, due to the non-linear relationship highlighted in Figure 6 between $S$ and $A_{s}: A$. Hence water spiralling length may be a better hydraulic indicator of water retention for metabolic activities, although it is intuitively less connected to the spatial area available for microbes and more related to stream size.

While $E R$ responded to the additional effects of temperature and water transient storage, this was not the case for GPP more related to water transient storage than temperature. This may partly explain why ER exceeds GPP in those groundwater fed streams (Demars et al., 2011). The synergistic model explained a larger amount of variance in $E R$ and was highly significant (Table II). However, it must be rejected because it had no biophysical meaning, showing interference effect when $E R$ is known to respond positively from both predictors (Fellows et al., 2001; Demars et al., 2011). Further sites need to be investigated to broaden the range of 
water transient storage under the full range of observed temperature $\left(5-25^{\circ} \mathrm{C}\right)$. This may also help to understand why storage residence time did not correlate to either GPP or ER.

The stream metabolic balance (NEP), at least during late summer, was therefore primarily driven by the temperature dependence of respiration. The differential in absolute metabolic activity (ER > GPP at $15{ }^{\circ} \mathrm{C}$; Demars et al., 2011) could not be explained by a differential response of ER and GPP to water transient storage, a surrogate for space availability for microbes. The metabolic balance of these streams was also likely influenced by dissolved organic carbon supply for bacterial activity (explaining ER $>$ GPP under steady state) and bicarbonate availability for photosynthetic organisms (Demars et al., 2011).

It is perhaps important to note that our field survey was not initially designed to test for the effect of water transient storage. While the data was suitable to address simple relationships, it was not enough to test for more complicated hypotheses. The results of such exploratory work should stimulate more controlled experiments in replicated flow through channels to test for the potential synergistic effects of water transient storage and temperature (e.g. Mulholland et al., 1994; Battin et al., 2003; Bottacin-Busolin et al., 2009).

This study concentrated on oxygenic metabolism; however other types of metabolic pathways may be favoured under higher temperature conditions. Hence, further work will need to quantify the proportion of aerobic metabolism (relative to all metabolic pathways) within the transient storage zone relative to the free-flowing zone (Haggerty et al., 2009) and try to disentangle the role of different types of transient storage zones with manipulative experiments (e.g. Ensign and Doyle, 2005).

\section{>IMPLICATIONS FOR RIVER MANAGEMENT AND RESTORATION}

We have demonstrated that under similar hydrological conditions, both temperature and transient storage are important drivers of stream metabolic activities. Transient storage is also a good descriptor of habitat complexity or spatial heterogeneity which has been demonstrated to increase biofilm metabolism (Cardinale et al., 2002). Higher metabolic activities will allow higher pollutant uptake or degradation (Sweeney et al., 2004; Stutter et al., 2010), hence river restoration and management should promote habitat diversity, especially for microbial activity (e.g. Bukaveckas, 2007; Power and Cardinale, 2009; Cardinale, 2011). While thermal pollution may have negative effects on local individual species (e.g. Langford, 1990), temperature generally increases biological activity in flowing waters (e.g. Demars et al., 2011), and this increased energy available to the food web may lead to longer food chain (Woodward et al., 2010) and increased fish production (Baum et al., 2005), as long as reaeration prevent substantial oxygen deficit (Moss, 2010).

While global climate change may alter the temperature of streams, changes in hydrological regime are predicted to have much more impact on aquatic metabolism (Acuña and Tockner, 2010). Since stream hydraulics respond to hydrological changes, such as the negative correlation between watertransient storage $\left(A_{s}: A\right)$ and stream discharge $(Q)$ (Manson et al., 2010), it is also through local hydraulic changes that global climate change may affect most stream metabolism.

\section{CONCLUSION}

The additional effect of water transient storage and temperature on $E R$ was identified for the first time. The predicted synergistic effect, a novel hypothesis, could not be confirmed however, likely due to data limitation. This may best be tested in more controlled conditions. Surprisingly, GPP responded more to water transient storage than to temperature. The metabolic balance of stream was therefore primarily affected by the temperature dependence of $E R$. This study suggests that river restoration aiming to increase stream metabolism should promote habitat diversity and complexity, especially for microbial activity. 


\section{ACKNOWLEDGEMENTS}

This study was funded by the Scottish Government Rural and Environment Research and Analysis Directorate (RERAD), now Rural and Environment Science and Analytical Services (RESAS). J.R.M. acknowledges the support of the Richard Stockton College of New Jersey. We would like to thank Tryggvi Thordarson, director of the Research Station at Hveragerdi for lodging and his warm hospitality, Marc Stutter and two anonymous referees for their insightful comments on the manuscript.

\section{REFERENCES}

Acuña V. and Tockner K., 2010. The effects of alterations in temperature and flow regime on organic carbon dynamics in Mediterranean river networks. Glob. Chang. Biol., 16, 2638-2650.

Alexander R.B., Smith R.A., Schwarz G.E., Boyer E.W., Nolan J.V. and Brakebill J.W., 2008. Differences in phosphorus and nitrogen delivery to the gulf of Mexico from the Mississippi river basin. Environ. Sci. Technol., 42, 822-830.

Alexander R.B., Bohlke J.K., Boyer E.W., David M.B., Harvey J.W., Mulholland P.J., Seitzinger S.P., Tobias C.R., Tonitto C. and Wollheim W.M., 2009. Dynamic modeling of nitrogen losses in river networks unravels the coupled effects of hydrological and biogeochemical processes. Biogeochemistry, 93, 91-116.

Argerich A., Marti E., Sabater F., Ribot M., von Schiller D. and Riera J.L., 2008. Combined effects of leaf litter inputs and a flood on nutrient retention in a Mediterranean mountain stream during fall. Limnol. Oceanogr., 53, 631-641.

Arnason B., Theodorsson P., Björnsson S. and Saemundsson K., 1969. Hengill, a high temperature thermal area in Iceland. Bull. Volcanol., 33, 245-259.

Battin T.J., Kaplan L.A., Newbold J.D. and Hansen C.M.E., 2003. Contributions of microbial biofilms to ecosystem processes in stream mesocosms. Nature, 426, 439-442.

Battin T.J., Kaplan L.A., Findlay S., Hopkinson C.S., Marti E., Packman A.I., Newbold J.D. and Sabater F., 2008. Biophysical controls on organic carbon fluxes in fluvial networks. Nature Geosci., 1, 95-100.

Battin T.J., Luyssaert S., Kaplan L.A., Aufdenkampe A.K., Richter A. and Tranvik L.J., 2009. The boundless carbon cycle. Nature Geosci., 2, 598-600.

Baum D., Laughton R., Armstrong J.D. and Metcalfe N.B., 2005. The effect of temperature on growth and early maturation in a wild population of Atlantic salmon parr. J. Fish Biol., 67, 1370-1380.

Bencala K.E. and Walters R.A., 1983. Simulation of solute transport in a mountain pool-and-riffle stream: a transient storage model. Wat. Resour. Res., 19, 718-724.

Bernot M.J., Sobota D.J., Hall R.O., Mulholland P.J., Dodds W.K., Webster J.R., Tank J.L., Ashkenas L.R., Cooper L.W., Dahm C.N., Gregory S.V., Grimm N.B., Hamilton S.K., Johnson S.L., McDowell W.H., Meyer J.L., Peterson B., Poole G.C., Valett H.M., Arango C., Beaulieu J.J., Burgin A.J., Crenshaw C., Helton A.M., Johnson L., Merriam J., Niederlehner B.R., O’Brien J.M., Potter J.D., Sheibley R.W., Thomas S.M. and Wilson K., 2010. Inter-regional comparison of land-use effects on stream metabolism. Freshwat. Biol., 55, 1874-1890.

Bottacin-Busolin A., Singer G., Zaramella M., Battin T.J. and Marion A., 2009. Effects of streambed morphology and biofilm growth on the transient storage of solutes. Environ. Sci. Technol., 43, 7337-7342.

Bukaveckas P.A., 2007. Effects of channel restoration on water velocity, transient storage, and nutrient uptake in a channelized stream. Environ. Sci. Technol., 41, 1570-1576.

Cardinale B.J., 2011. Biodiversity improves water quality through niche partitioning. Nature, 472, 86-89.

Cardinale B.J., Palmer M.A., Swan C.M., Brooks S. and Poff N.L., 2002. The influence of substrate heterogeneity on biofilm metabolism in a stream ecosystem. Ecology, 83, 412-422.

Constantz J., 1998. Interaction between stream temperature, streamflow, and groundwater exchanges in alpine streams. Wat. Resour. Res., 34, 1609-1615.

Constantz J. and Murphy F., 1991. The temperature dependence of ponded infiltration under isothermal conditions. J. Hydrol., 122, 119-128. 
Cox T.J. and Runkel R.L., 2008. Eulerian-Lagrangian numerical scheme for simulating advection, dispersion, and transient storage in streams and a comparison of numerical methods. J. Environ. Eng., 134, 996-1005.

Demars B.O.L., Manson J.R., Olafsson J.S., Gislason G.M., Gudmundsdottir R., Woodward G., Reiss J., Pichler D.E., Rasmussen J.J. and Friberg N., 2011. Temperature and the metabolic balance of streams. Freshw. Biol., 56, 1106-1121.

Ensign S.H. and Doyle M.W., 2005. In-channel transient storage and associated nutrient retention: Evidence from experimental manipulations. Limnol. Oceanogr., 50, 1740-1751.

Fellows C.S., Valett H.M. and Dahm C.N., 2001. Whole-stream metabolism in two montane streams: contribution of the hyporheic zone. Limnol. Oceanogr., 46, 523-531.

Friberg N., Dybkjaer J.B., Olafsson J.S., Gislason G.M., Larsen S.E. and Lauridsen T.L., 2009. Relationships between structure and function in streams contrasting in temperature. Freshw. Biol., 54, 2051-2068.

Haggerty R., Marti E., Argerich A., von Schiller D. and Grimm N.B., 2009. Resazurin as a "smart" tracer for quantifying metabolically active transient storage in stream ecosystems. J. Geophys. Res.Biogeosci., 114, G03014.

Hart D.R., Mulholland P.J., Marzolf E.R., DeAngelis D.L. and Hendricks S.P., 1999. Relationships between hydraulic parameters in a small stream under varying flow and seasonal conditions. Hydrol. Process., 13, 1497-1510.

Hoffman J.D., 1992. Numerical Methods for Engineers and Scientists, McGraw-Hill.

Jones J.B. and Mulholland P.J. (eds.), 2000. Streams and Ground Waters, Academic Press, San Diego.

Lagarias J.C., Reeds J.A., Wright M.H. and Wright P.E., 1998. Convergence properties of the Nelder-Mead simplex method in low dimensions. SIAM J. Optim., 9, 112-147.

Langford T.E.L., 1990. Ecological Effects of Thermal Discharges, Elsevier Applied Science, Barking.

Manson J.R. and Wallis S.G., 1995. An accurate numerical algorithm for advective transport. Commun. Numer. Methods. Eng., 11, 1039-1045.

Manson J.R. and Wallis S.G., 2000. A conservative, semi-Lagrangian fate and transport model for fluvial systems: Part 1 - Theoretical development. Water Resour., 34, 3769-3777.

Manson J.R., Wallis S.G. and Hope D., 2001. Conservative semi-Lagrangian transport model for rivers with transient storage zones. Wat. Resour. Res., 37, 3321-3329.

Manson J.R., Demars B.O.L., Wallis S.G. and Mytnik V., 2010. A combined computational and experimental approach to quantifying habitat complexity in Scottish upland streams. In: Proceedings of Hydropredict' 2010, International Interdisciplinary Conference on Predictions for Hydrology, Ecology and Water Resource Management, Prague, Czech Republic, Paper No. 191, available at http://www.iahs.info/conferences/CR2010/2010_Praha/full/191.pdf .

Manson J.R., Demars B.O.L. and Wallis S.G., 2011. Integrated experimental and computational hydraulic science in a unique natural laboratory. In: Rowinski P. (ed.), Experimental Methods in Hydraulic Research, Geoplanet: Earth and Planetary Sciences, Springer Book Series, 123-131.

Marti E., Fonolla P., von Schiller D., Sabater F., Argerich A., Ribot M. and Riera J.L., 2009. Variation in stream $\mathrm{C}, \mathrm{N}$ and $\mathrm{P}$ uptake along an altitudinal gradient: a space-for-time analogue to assess potential impacts of climate change. Hydrol. Res., 40, 123-137.

Marzolf E.R., Mulholland P.J. and Steinman A.D., 1994. Improvements to the diurnal upstreamdownstream dissolved oxygen change technique for determining whole-stream metabolism in small streams. Can. J. Fish. Aquat. Sci. , 51, 1591-1599.

Moss B., 2010. Climate change, nutrient pollution and the bargain of Dr. Faustus. Freshw. Biol., 55, $175-187$.

Mulholland P.J., Steinman A.D., Marzolf E.R., Hart D.R. and Deangelis D.L., 1994. Effect of periphyton biomass on hydraulic characteristics and nutrient cycling in streams. Oecologia, 98, 40-47.

Mulholland P.J., Marzolf E.R., Webster J.R., Hart D.R. and Hendricks S.P., 1997. Evidence that hyporheic zones increase heterotrophic metabolism and phosphorus uptake in forest streams. Limnol. Oceanogr., 42, 443-451.

Mulholland P.J., Fellows C.S., Tank J.L., Grimm N.B., Webster J.R., Hamilton S.K., Marti E., Ashkenas L., Bowden W.B., Dodds W.K., McDowell W.H., Paul M.J. and Peterson B.J., 2001. Inter-biome comparison of factors controlling stream metabolism. Freshw. Biol., 46, 1503-1517.

Odum H.T., 1956. Primary production in flowing waters. Limnol. Oceanogr., 1, 102-117. 
Power L.D. and Cardinale B.J., 2009. Species richness enhances both algal biomass and rates of oxygen production in aquatic microcosms. Oikos, 118, 1703-1711.

Sand-Jensen K. and Mebus J.R., 1996. Fine-scale patterns of water velocity within macrophyte patches in streams. Oikos, 76, 169-180.

Stutter M.I., Demars B.O.L. and Langan S.J., 2010. River phosphorus cycling: Separating biotic and abiotic uptake during short-term changes in sewage effluent loading. Water Resour., 44, 4425-4436.

Swanson T.E. and Cardenas M.B., 2010. Diel heat transport within the hyporheic zone of a pool-rifflepool sequence of a losing stream and evaluation of models for fluid flux estimation using heat. Limnol. Oceanogr., 55, 1741-1754.

Sweeney B.W., Bott T.L., Jackson J.K., Kaplan L.A., Newbold J.D., Standley L.J., Hession W.C. and Horwitz R.J., 2004. Riparian deforestation, stream narrowing, and loss of stream ecosystem services. Proc. Nat. Acad. Sci. USA, 101, 14132-14137.

Vörösmarty C.J., Mclntyre P.B., Gessner M.O., Dudgeon D., Prusevich A., Green P., Glidden S., Bunn S.E., Sullivan C.A., Liermann C.R. and Davies P.M., 2010. Global threats to human water security and river biodiversity. Nature, 467, 555-561.

Woodward G., Dybkjaer J.B., Olafsson J.S., Gislason G.M., Hannesdottir E.R. and Friberg N., 2010. Sentinel systems on the razor's edge: effects of warming on Arctic geothermal stream ecosystems. Glob. Chang. Biol., 16, 1979-1991. 